Article

\title{
Self-Reinforcing Processes Governing Urban Sprawl in Belgium: Evidence over Six Decades
}

\author{
Ahmed Mustafa ${ }^{1}(1)$ and Jacques Teller ${ }^{2, *}$ (i) \\ 1 Urban Systems Lab, The New School, New York, NY 10003, USA; a.mustafa@newschool.edu \\ 2 Local Environment Management and Analysis, Liège University, 4000 Liège, Belgium \\ * Correspondence: jacques.teller@uliege.be
}

Received: 8 April 2020; Accepted: 15 May 2020; Published: 17 May 2020

check for updates

\begin{abstract}
Urban sprawl is widely acknowledged as an environmental and socio-economic challenge worldwide. This study examines urban sprawl in Belgium over six decades from 1950 to 2010. We assume that sprawl is a self-reinforcing process, i.e., sprawl is fueling further sprawl over time. The main objective of this study is to examine this assumption. We measure urban sprawl at four different levels in this study: country, regions, municipalities, and $1-\mathrm{km}^{2}$ cells. Three sprawl indices are employed: the degree of urban dispersion, degree of urban permeation of the landscape, and built-up land uptake per capita. These three indices consider both the growth of built-up areas and population density to measure the magnitude of sprawl. The drivers of urban sprawl have been analyzed at a $1-\mathrm{km}^{2}$ level. The examined drivers are previous urban dispersion patterns, distance to urban cores, elevation, and slope degree by means of linear regression. Urban sprawl significantly increased between 1950 and 1980, whereas its increase was more moderate between 1980 and 2010. Urban dispersion and permeation strongly affect the Brussels and Flanders regions. The results show that the increase in the degree of dispersion is locally driven by previous values of dispersion; i.e., it provides an adequate milieu for further dispersion. Therefore, our conclusion is that urban sprawl in Belgium tends to be a self-reinforcing process.
\end{abstract}

Keywords: urban sprawl; degree of dispersion; urban permeation; Belgium; self-reinforcing process

\section{Introduction}

Urban sprawl represents one of the most vexing challenges facing the sustainability agenda in several countries; these countries try to control sprawl by turning to urban planning that limits the use of automobiles and by promoting high-density development [1]. Even though there are numerous, conflicting definitions of urban sprawl, this phenomenon is basically characterized by urban areas growing faster than their populations, causing urban densities to fall [2]. For example, Ewing et al. [3] defined sprawl as "as low-density development with residential, shopping, and office areas that are rigidly segregated; a lack of thriving activity centers; and limited choices in travel routes". Undoubtedly, sprawl is associated with a number of ecological, economic, and socially negative implications. For example, urban sprawl causes the loss of fertile arable lands and the loss of ecological soil functions. Sprawl also leads to higher greenhouse gas emissions and air pollution, higher infrastructure costs, and an increase in traffic congestion $[4,5]$. Therefore, the urban sprawl phenomenon has attracted attention from researchers, planners, and policymakers. For instance, Hennig et al. [6] identified the regions of highest and lowest levels of urban sprawl in Europe and proposed a European de-sprawling strategy to limit sprawl. They found that sprawl highly impacted regions in the west and center of Europe as well as along the Mediterranean coast. Halleux et al. [7] compared the measurements to control sprawl in the Netherlands, Belgium, and Poland. Other studies 
measured urban sprawl and/or its drivers in the USA [8,9], Latin America [10-12], China [13,14], and Africa $[15,16]$.

After World War II, many EU countries experienced faster built-up expansion rates and more dispersed settlements [17]. According to the European Environment Agency [4], the sprawl level in Belgium is one of the highest among European countries. Land use planning policies in Belgium represent a long-established liberal attitude [18]. Historically, Belgian land use was mainly determined by individual landownership and market forces [7,19]. In the early 1900s, rural and property interests were able to prevent the effective control of development through land use plans in Belgium [7], which strongly affected both planning practices and spatial dispersal. This explains why land use (zoning) plans were not adopted in Belgium before the 1970s. Land use plans finally covered the entire territory in the early 1980s.

Understanding sprawl trends, characteristics, and drivers is crucial for planners and policymakers to limit the substantial increase of low-density residential and commercial areas outside of the city boundary, which causes numerous problems related to sprawl. In this article, our objective is to provide insights into the long-term evolution of urban sprawl in Belgium. More specifically, we aim to understand sprawl drivers and dynamics over time in Belgium, where sprawl degree is one of the highest among European countries. Our assumption is that urban sprawl is a self-reinforcing process in Belgium, i.e., those places where sprawl tends to increase more are the ones where it was already strong in previous periods. Such behavior would have strong policy implications as it would suggest that land use plans were not adequate at curbing urban sprawl, even though this was one of their crucial objectives. We therefore explicitly adopt a path-dependency approach, assuming that urban sprawl is influenced by territorial trajectories initiated in the early 1950s. Our analysis is hence conducted on a long-term basis, for six decades between 1950 and 2010, at four reporting units: country, region, municipality, and $1-\mathrm{km}^{2}$ cells.

Measuring the degree of urban sprawl has been done using various indices according to the definition and the aspects of urban sprawl. Generally speaking, there are two common approaches employed to measure sprawl phenomenon; either based on one index or based on a set of multiple indices. For example, Lopez et al. [20] measured sprawl based only on census data, whereas Solon [21] used several landscape metrics to measure the sprawl, e.g., mean patch size, mean shape index, mean nearest neighbor distance, and mean proximity index. Using multiple indices to measure sprawl has some drawbacks, such as the provision of redundant information [22]. More recent studies conceptualized urban sprawl as a multidimensional process [23,24], which is the approach adopted in this study. We therefore adopt three interrelated indices of urban sprawl, proposed by Hennig et al. and Jaeger et al. [6,23]: degree of urban dispersion (DIS), degree of urban permeation of the landscape (UP), and land uptake per inhabitant (LUP). Furthermore, this study analyzes the likely driving forces of urban sprawl at $1-\mathrm{km}^{2}$ reporting units. The examined drivers are former DIS degree, distance to cities, elevation, and slope degree. The definition of the most influential drivers is important in understanding the trends of sprawl over time.

The remainder of the paper is organized as follows. Section 2 introduces the study area. Section 3 presents the materials and methods. Section 4 lists and discusses our findings, and Section 5 gives our conclusions.

\section{Study Area}

Belgium is a federal state and it is quite accessible within Europe. The country shares borders with France, Germany, Luxembourg, and the Netherlands. The state is made up of three regions (Figure 1): Dutch-speaking "Flanders" to the north, French-speaking "Wallonia" to the south, and a bilingual capital "Brussels" in the middle. It covers an area of $30,528 \mathrm{~km}^{2}$ and has a population of about 11.4 million. About $57 \%$ of the Belgian population live in towns, which cover about $26 \%$ of the Belgian territory [25]. The population density varies remarkably from 30 inhabitants $/ \mathrm{km}^{2}$ in rural locations to over 20,000 inhabitants $/ \mathrm{km}^{2}$ in highly urbanized cores [25]. 


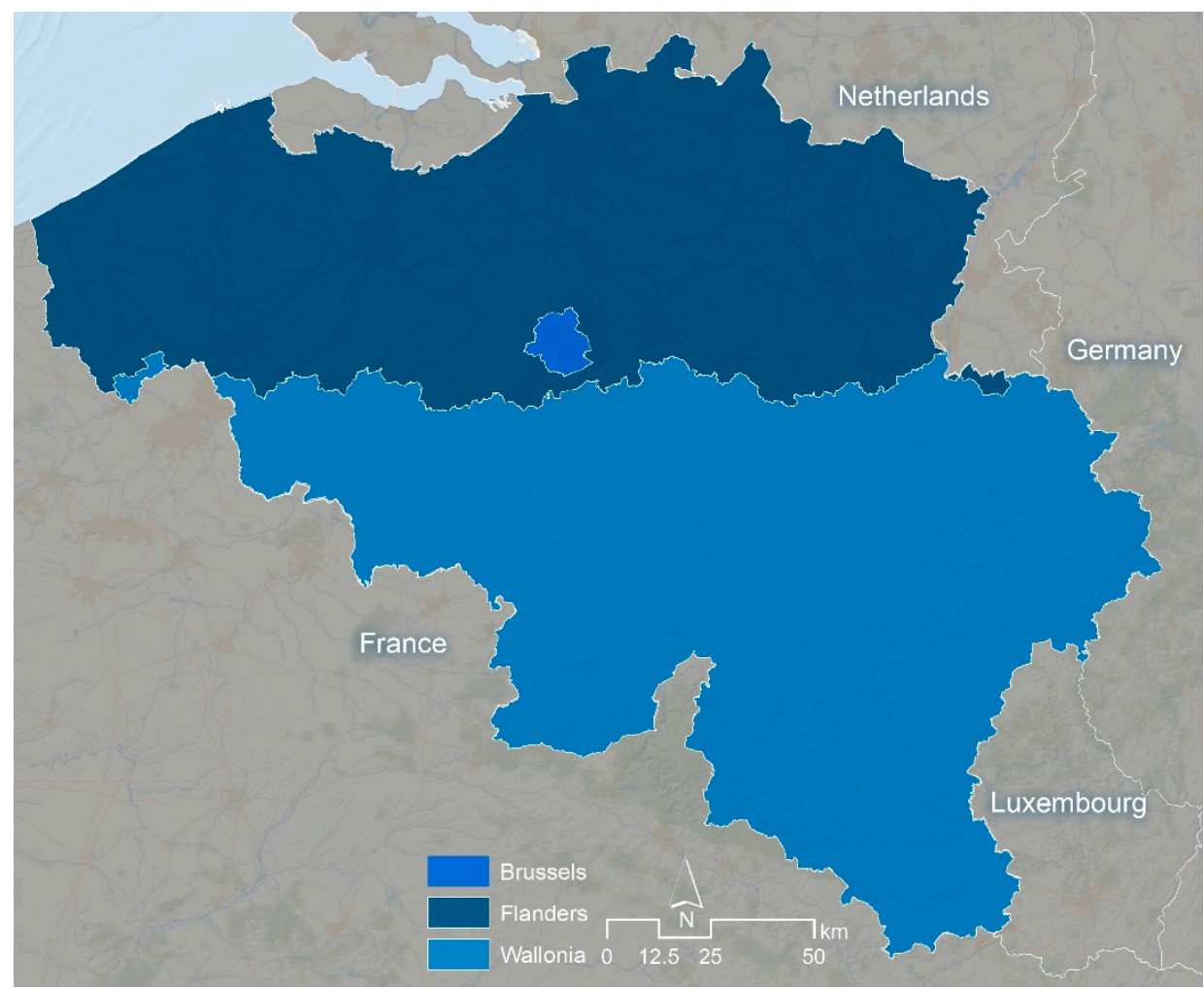

Figure 1. Study area (Belgium).

The capital, and the largest city, is Brussels, the home of the headquarters of the European Union and NATO. Other major cities are Antwerp, Ghent, Liege, and Charleroi. Urban sprawl highly affects the geography of Belgium. New urban developments are spreading in low density areas along transit route. Belgium has one of the highest densities of roads and the highest density of railroads in the world.

\section{Methods and Metrics}

This section presents the processing of data used in this study and the urban sprawl metrics.

\subsection{Data Processing}

Belgian cadastral data (CAD), provided by the land registry administration of Belgium, were used as a built-up dataset. CAD are vector data that provide information about all buildings in Belgium, including the construction date. Using the construction date, seven built-up maps were generated for 1950, 1960, 1970, 1980, 1990, 2000, and 2010. The vector data were rasterized and aggregated at $100 \mathrm{~m} \times 100 \mathrm{~m}$ using two procedures: minimum building density per cell and the minimum building density per neighbor, following Mustafa et al. [26]. The aggregated data were then classified into built-up and non-built-up. The built-up areas in this study include various types of settlements including cities, villages, and individual buildings in remote locations $[27,28]$. Road networks and railroads are not considered as built-up areas.

Other supplementary data were geo-processed to help explain the urban sprawl drivers. These sources included population volume (published by The Walloon Institute for Evaluation, Prospective, and Statistics), digital elevation models (derived from the Belgian National Geographic Institute), and distance to 34 major cities and urban cores in Belgium. 


\subsection{Measuring Sprawl}

In this study, we used three indices of urban sprawl, proposed by Hennig et al. and Jaeger et al. [6,23], Table 1: degree of urban dispersion (DIS), degree of urban permeation of the landscape (UP), and land uptake per inhabitant (LUP). The first two indices consider geometrical aspects of urban settlements, whereas the LUP considers the relationship between built-up expansion and population growth. It is important to consider the population when measuring sprawl because not all form of built-up expansions should be counted as urban sprawl. Fulton et al. [29] suggested that an increase in a built-up area can only be counted as sprawl if the land is consumed at a faster rate than the population growth. DIS is based on the distances between any two points within built-up areas within the horizon of perception (HP). The HP is the scale of analysis of urban sprawl. There are only minor differences in the DIS values as they are measured by HPs between $1 \mathrm{~km}$ and $5 \mathrm{~km}$ [4]; therefore, we set the HP at $2 \mathrm{~km}$ in this study. The UP measures the degree of landscape permeation by built-up settlements and detached buildings. It equals the built-up area within the reporting unit multiplied by DIS. The units of DIS and UP is the urban permeation unit (UPU) $/ \mathrm{m}^{2}$, as detailed in [4]. LUP equals the built-up area divided by the total inhabitants within the reporting unit and is measured as inhabitants/built-up area in hectares (ha) within the reporting unit. For three of the reporting units (country, regions, and municipalities) we calculated the three sprawl indices. The population data is not available at the $1-\mathrm{km}^{2}$ reporting unit in Belgium and therefore we only measured DIS and UP for the $1-\mathrm{km}^{2}$ reporting unit.

Table 1. Formulas for degree of urban dispersion (DIS), urban permeation of the landscape (UP), and land uptake per inhabitant (LUP) with horizon of perception $(\mathrm{HP})=2 \mathrm{~km}[6,23]$.

\begin{tabular}{|c|c|}
\hline $\operatorname{DIS}(b)=\frac{1}{n} \sum_{i=1}^{n} \frac{1}{n_{i}}\left(\sum_{j=1}^{n_{i}} f\left(d_{i j}\right)+\operatorname{WCC}(b)\right)$ & $\begin{array}{c}b \text { : cell width } \\
n_{i}: \text { number of built-up cells that are closer to cell } i \text { than } H P \\
d_{i j}: \text { distance between cell } i \text { and cell } j \\
W C C(b) \text { : the within-cell contribution } \\
W C C(b)=(0.97428 \times b+1.046)^{0.5}-0.996249\end{array}$ \\
\hline \multicolumn{2}{|l|}{$U P(b)=b^{2} n \times D I S(b)$} \\
\hline$L U P=\frac{\text { built }- \text { up area }}{N_{\text {inh }}}$ & $N_{i n h}:$ number of inhabitants \\
\hline
\end{tabular}

This study employed a linear regression model to explore the drivers of urban sprawl in Belgium at the finest reporting unit $\left(1-\mathrm{km}^{2}\right)$. The dependent variable represents the change in the DIS for each 10-year period (delta DIS). The independent variables are the degree of DIS at the former period, the Euclidean distance to the centers of 34 urban cores in Belgium, elevation, and slope degree. The selection of delta DIS as a dependent variable was made according to the recommendation of [4], as urban sprawl mainly denotes in an increase of DIS or LUP. As LUP could not be calculated at the 1-km² reporting unit, we selected delta DIS as our dependent variable. It was indeed considered that working with smaller reporting units would provide more reliable results for statistical reasons as this provides larger samples and independent variables calculated on smaller units. Furthermore, urban sprawl can vary a lot at an infra-municipal level. All independent variables were standardized prior to performing the regression analysis so that we could compare the coefficients of different types of variables.

\section{Results and Discussion}

This section presents the trends of urban sprawl in Belgium between 1950 and 2010 for the four different reporting units (country, regions, municipalities, $1-\mathrm{km}^{2}$ cells). The country reporting unit gives general trends of overall sprawl in Belgium. The regional unit allows us to compare the general sprawl trends between the three regions. The results at the municipal and $1-\mathrm{km}^{2}$ levels give more informative details of sprawl and reveal the spatial variation in sprawl on a local scale.

Figure 2 shows the evolution of built-up area for the different study periods. The observed urban expansion trends showed a steep upward trend until 1980, representing rapid urban development 
between 1950 and 1980, and then it gradually slows down in Belgium. The regional trends indicate that urban development in Flanders is significantly higher than in Wallonia. Flanders covers $44 \%$ of Belgium territory and shares about $64 \%$ of the urban area in Belgium. On the other hand, Wallonia covers more than $55 \%$ of Belgium and shares only $34 \%$ of Belgian built-up areas. Brussels also shows a high rate of urban development as it covers about $0.5 \%$ of Belgium and shares $2 \%$ of the built-up land in Belgium.

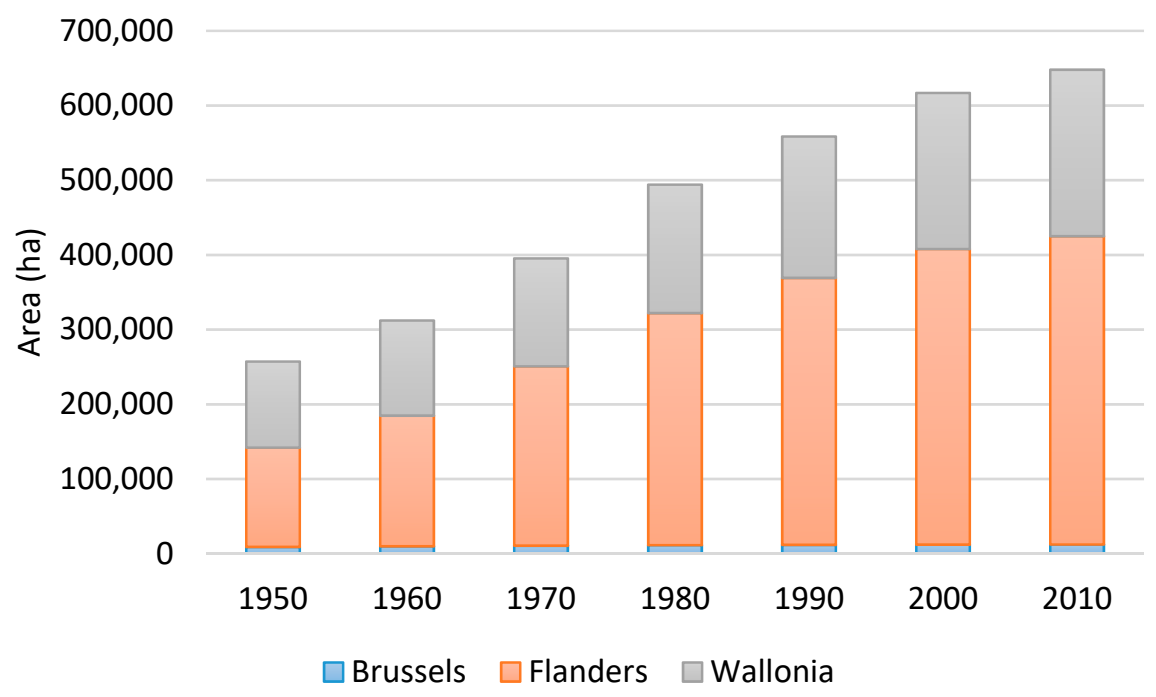

Figure 2. Built-up area (ha) in Belgium.

DIS in Belgium in 2010 was 47.4, which represents a higher urban dispersion pattern than the average dispersion in other European countries (average DIS in EU countries in 2009 was 44.8) [4]. DIS analysis (Figure 3) reveals a significant increase in the 1960s and the 1970s, which reflects the shift from a train-based to a car-based community in the 1950s. More interestingly, DIS increased uniformly with the increasing urban area in all regions except for Brussels. In 2010, Brussels showed a slight increase in built-up area, with a decrease in DIS, meaning that new urban areas between 2000 and 2010 were located nearby or within existing urban areas. UP values (Figure 4) demonstrate that the landscape in Brussels is permeated by urban settlements two times more than in other regions. This is quite logical because there is a shortage of available land in the Brussels Capital Region.

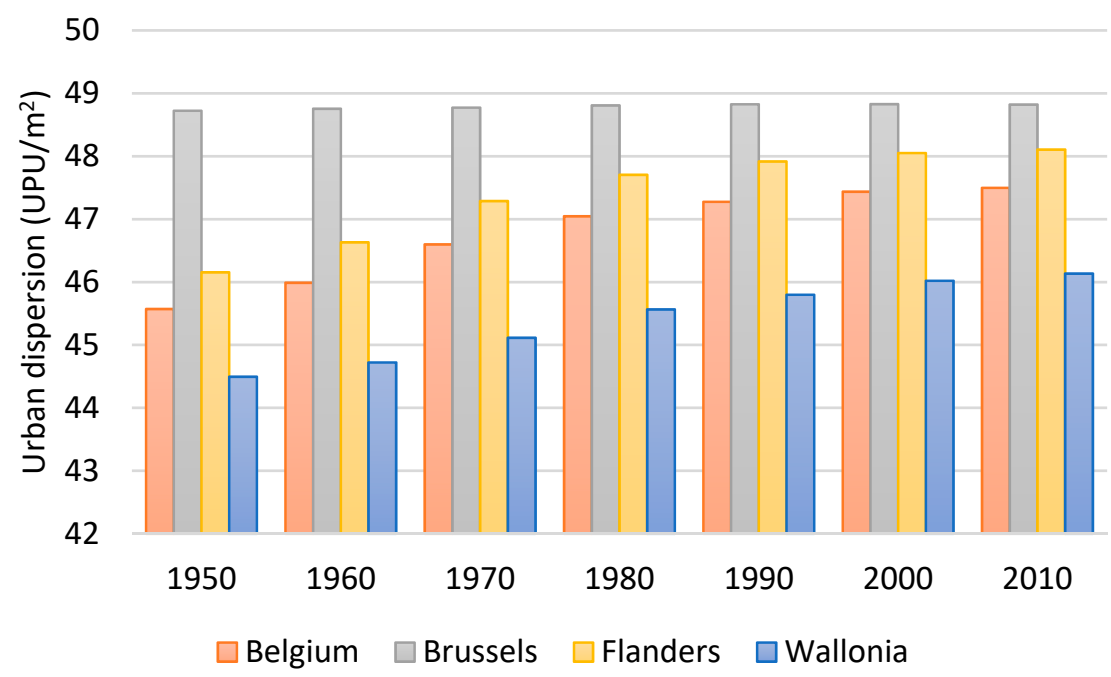

Figure 3. DIS value $\left(\mathrm{UPU} / \mathrm{m}^{2}\right)$. 


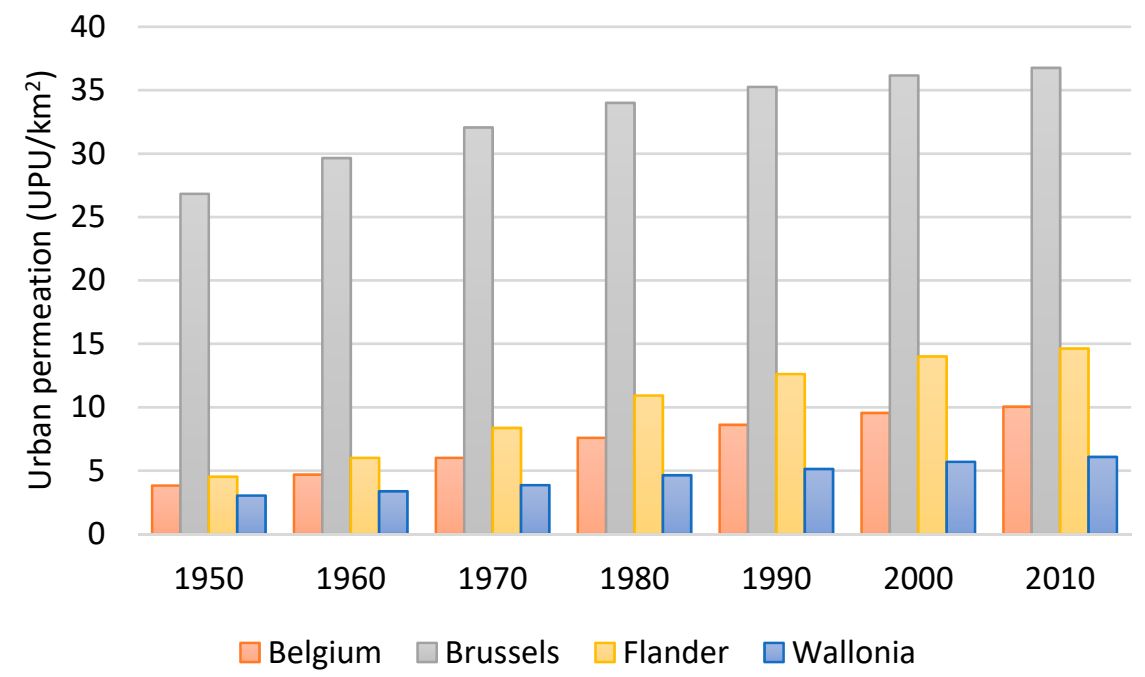

Figure 4. UP $\left(\mathrm{UPU} / \mathrm{km}^{2}\right)$.

LUP in Belgium (Figure 5) uniformly increased until 2000, then slightly decreased, with about 0.06 ha of built-up area per inhabitant in 2010. Yet, this is two times the average value of LUP in European countries ( 0.03 ha per inhabitant) [4]. However, the results show a strong variation between regions. The LUP in Wallonia and Flanders exceeds 0.06 ha, whereas Brussels has a remarkably lower LUP value that barely exceeds 0.01 . This can be explained by the fact that, in Flanders and Wallonia, many households live in individual homes while apartments are much more widespread in Brussels.

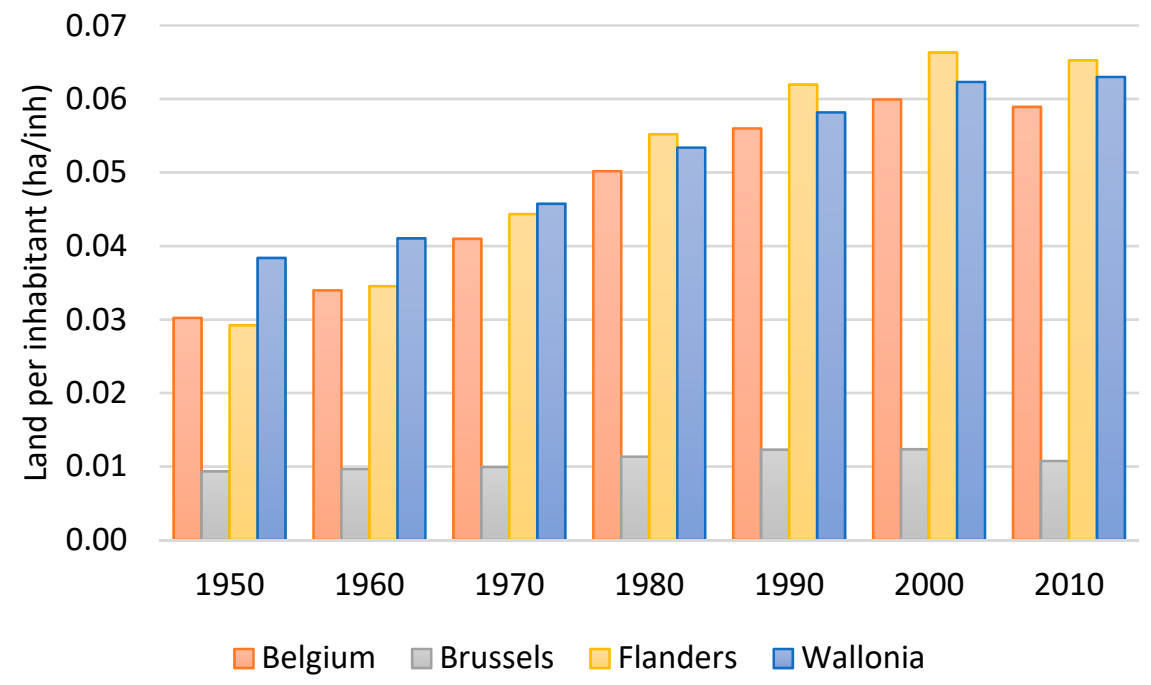

Figure 5. LUP (ha/inhabitants).

Generally speaking, Belgium is characterized by a long-established urban sprawl. It entered the 1960s without zoning regulations, which has had long-term consequences on urban sprawl. The development of land use plans for the three regions, during the 1970s and 1980s, led to a slight reduction in the progression of urban sprawl (Figures 2-5). However, those plans need reviewing and updating as Belgium still suffers from sprawl. The land use plans allow for linear residential extensions, with oversized residential zones and permit ribbon extensions in the suburbs [7]. As land use plans do not prescribe densities, they are quite inefficient for promoting in-fill development. This is in line with the findings of Halleux et al. [7] who concluded that Belgium still faces difficulties in the control of urban sprawl even after implementing land use plans. 
The findings at the municipal reporting unit level indicate that the highest values of DIS and UP are always found in the northern and central municipalities of Belgium, whereas the highest LUP can be found in the municipalities to the south and northeast. Figure 6 presents the DIS values in 2010. It also qualitatively shows the difference in dispersion between two municipalities with high and low DIS.

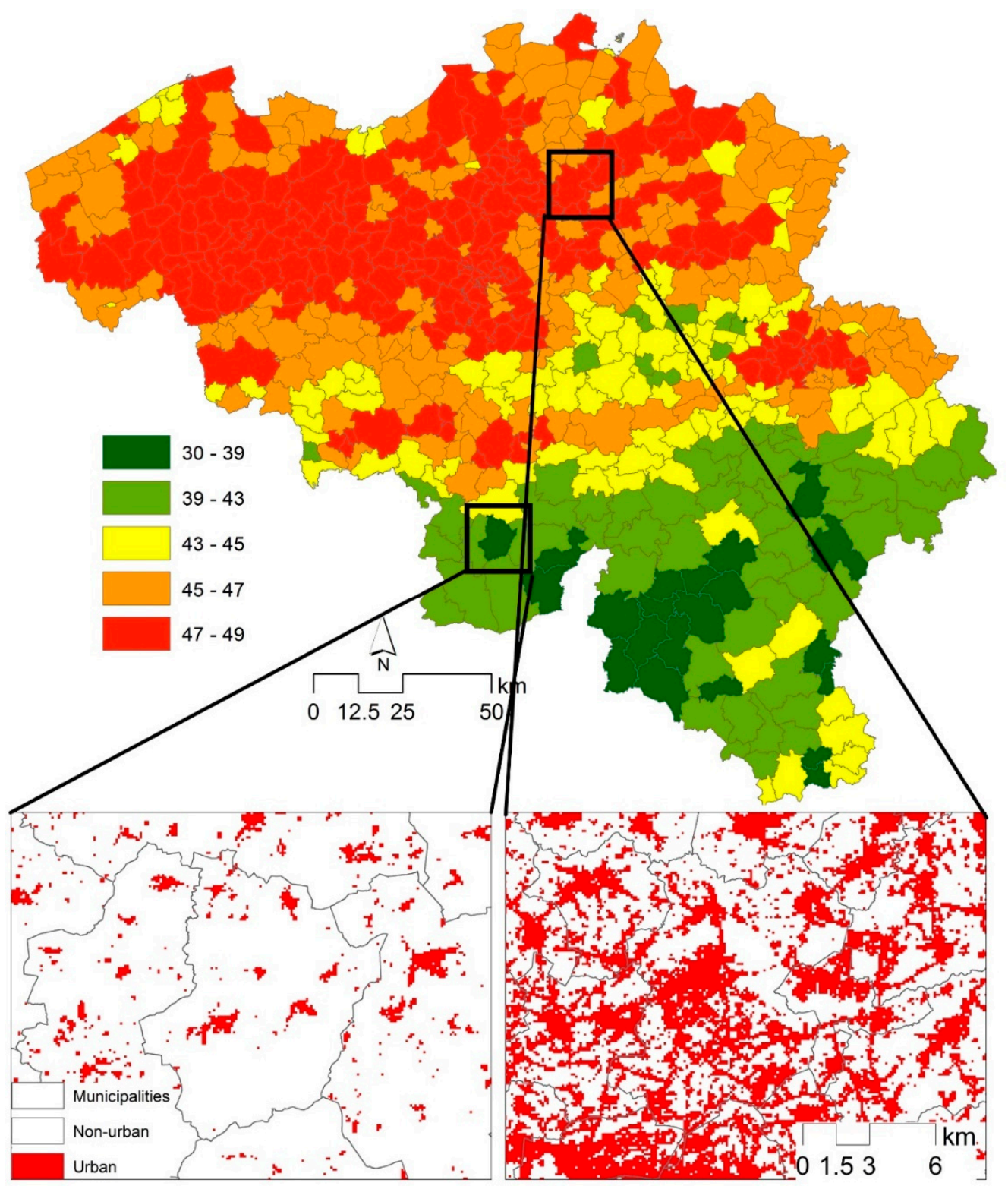

Figure 6. DIS in 2010 (municipal reporting unit).

Table 2 summarizes the results at the municipal reporting unit level. The table indicates that the variance in DIS between municipalities decreased over time, with standard deviation (SDiv) values of 3.47 and 2.55 for 1950 and 2010, respectively. This is mainly due to a sharp increase in the minimal values of dispersion while maximal values remain somehow stable over time. On the contrary, the SDiv of UP and LUP remarkably increased over time, implying that the differences in UP and LUP rates among municipalities are getting higher with time. In other words, dispersion (DIS) is increasing all over Belgium through a form of homogenization of sprawl. Still, the dispersion of built-up areas all over the territory is not followed by a densification of the population in peri-urban areas.

Figures 7-9 demonstrate the change in DIS, UP, and LUP in Belgium in each decade between 1950 and 2010. Increases in DIS were more prevalent than decreases in DIS, particularly between 
1950 and 1970 in Flanders and between 1970 and 1990 in Wallonia. In addition, DIS slightly increased in most municipalities between 1990 and 2010, but there were some municipalities, especially in Flanders, in which DIS decreased during this period. LUP significantly increased in a large number of municipalities of the northeast, northwest, and southwest between 1950 and 1990. The change in LUP starts declining in the majority of municipalities, especially during the 2000-2010 period.
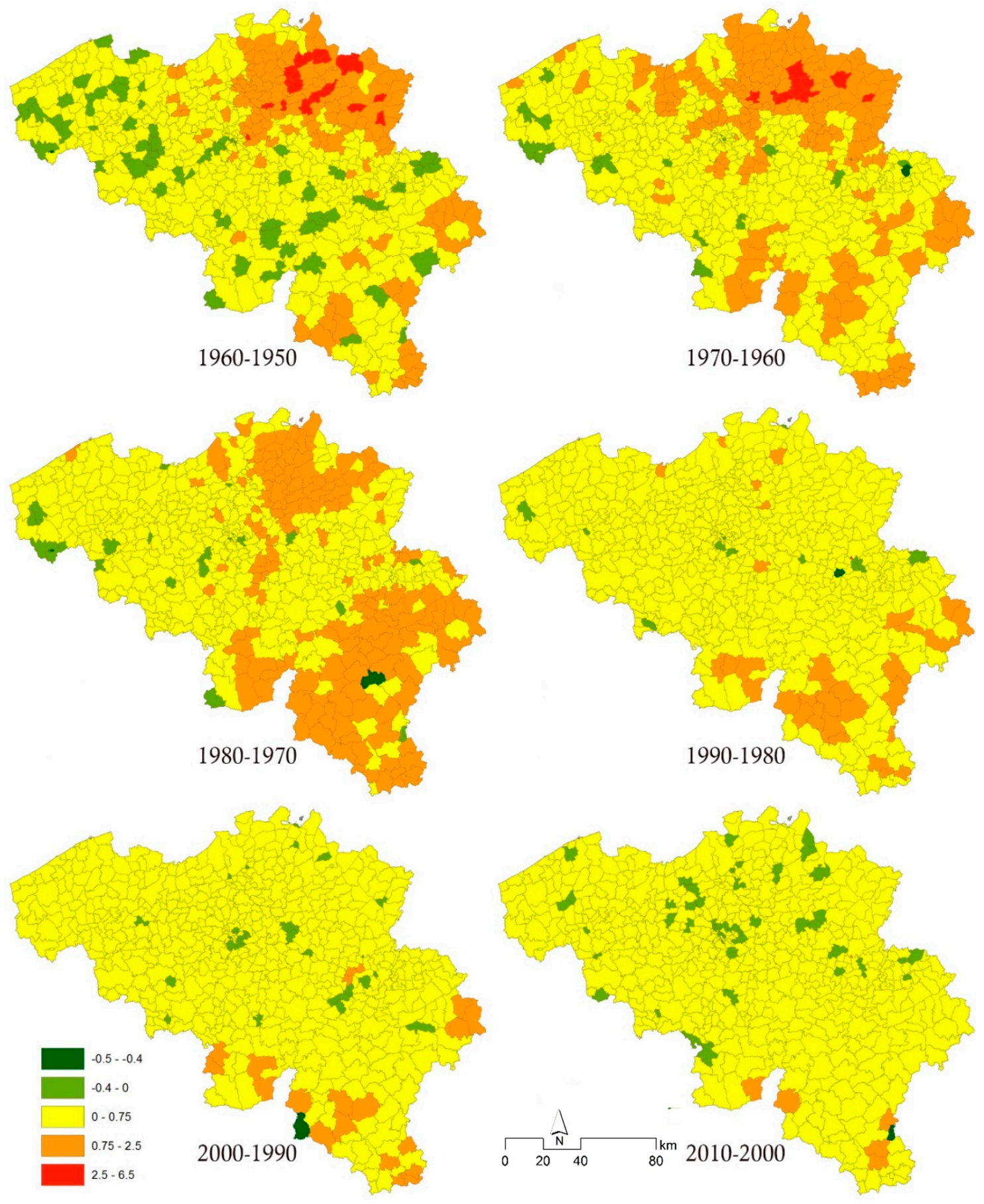

Figure 7. Changes in DIS at the municipal reporting unit. 

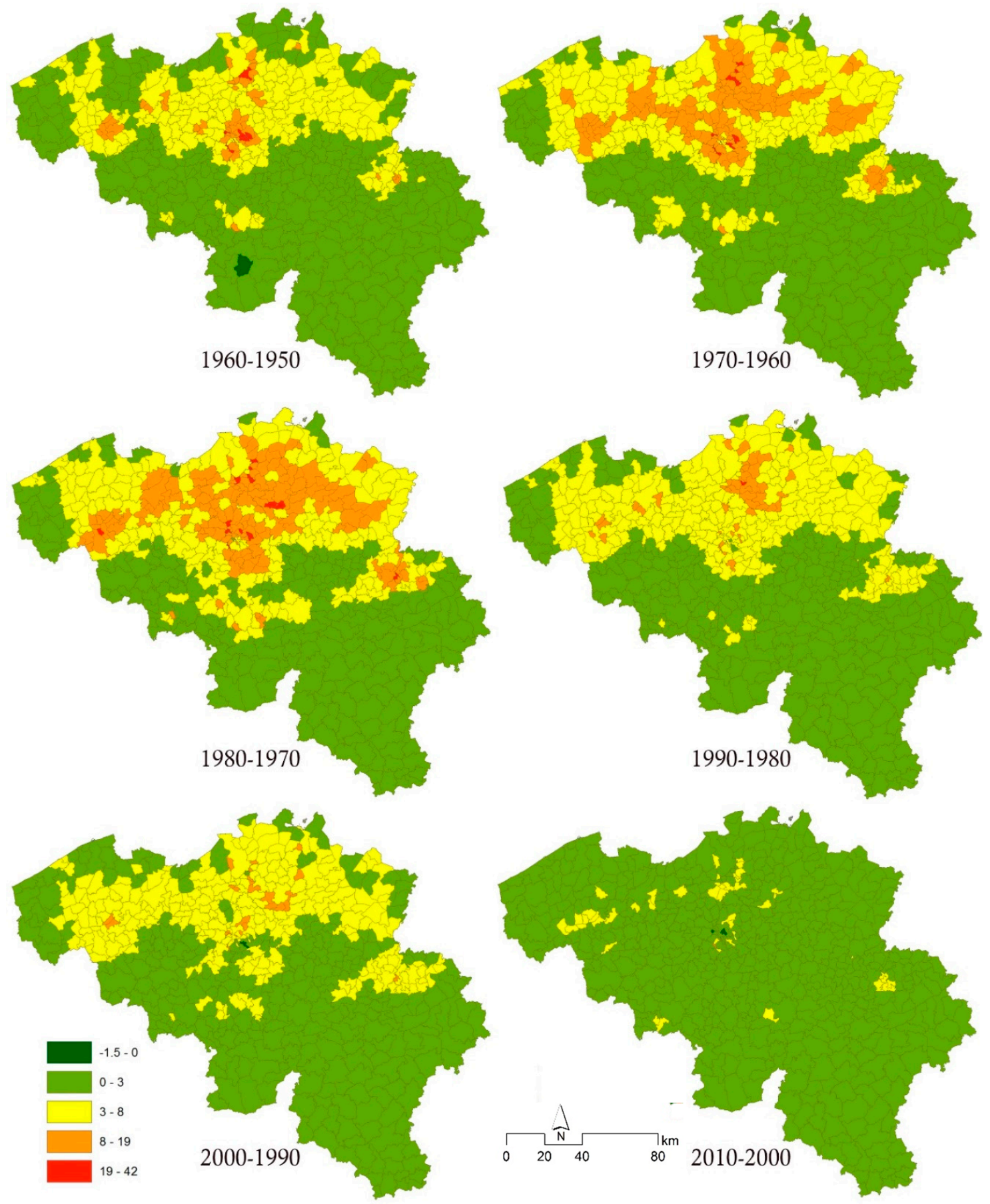

Figure 8. Changes in UP at the municipal reporting unit. 

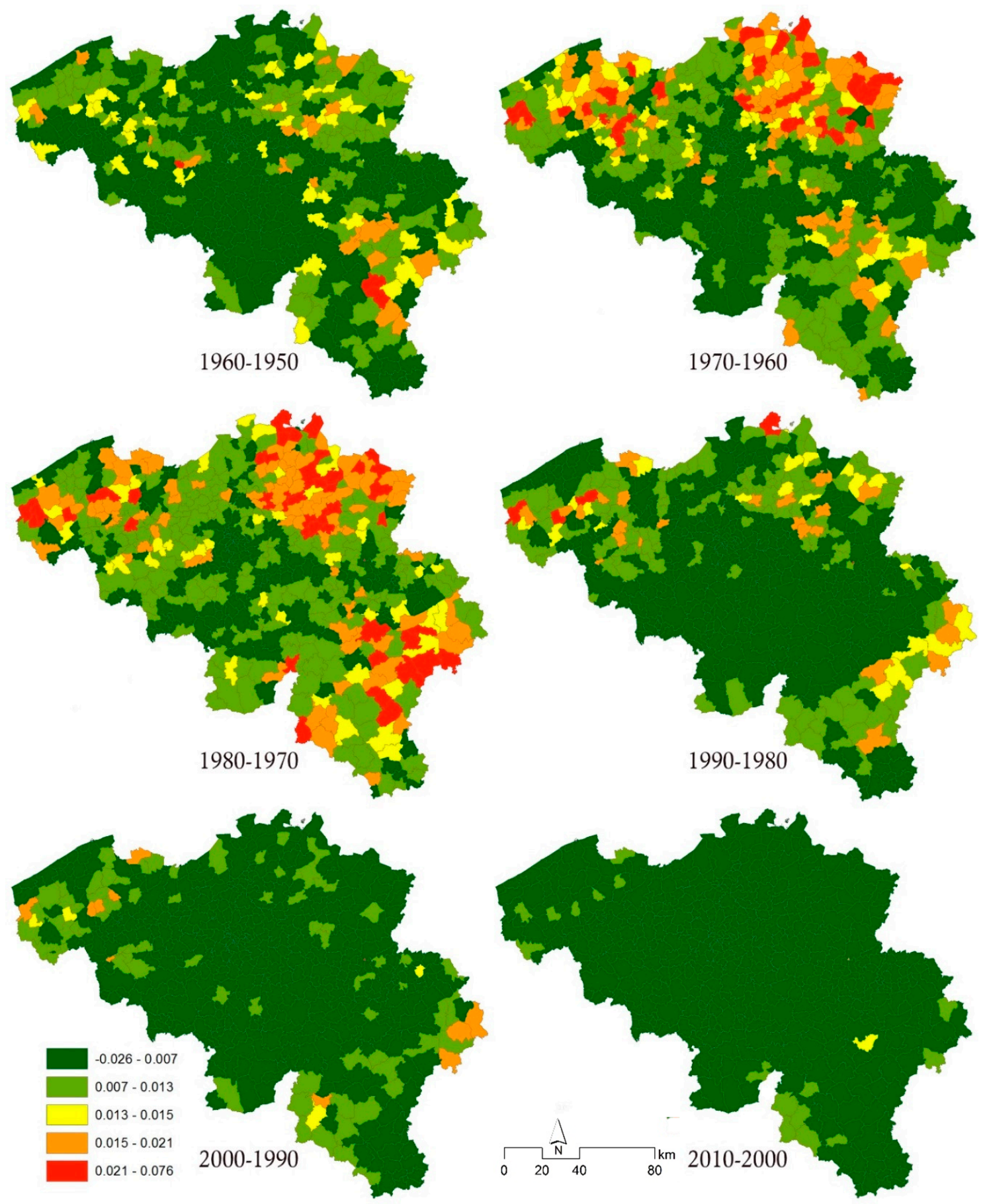

Figure 9. Changes in LUP at the municipal reporting unit.

The results at the $1-\mathrm{km}^{2}$ reporting unit level allow the identification of areas most affected by sprawl. There is a remarkable increase in DIS between 1950 and 2010 (Figure 10) in Flanders and Brussels (northern Belgium) and the along the 19th-century industrial axis of northern Wallonia, running from east (Liege) to west (Mons). Additionally, UP obviously reveals the polycentric pattern of sprawl in Belgium, particularly in 2010. 
Table 2. Indicators of DIS (UPU/ $\left.\mathrm{m}^{2}\right)$, UP $\left(\mathrm{UPU} / \mathrm{km}^{2}\right)$, and LUP (ha/inh) at the municipal reporting unit level.

\begin{tabular}{cccccccc}
\hline & $\mathbf{1 9 5 0}$ & $\mathbf{1 9 6 0}$ & $\mathbf{1 9 7 0}$ & $\mathbf{1 9 8 0}$ & $\mathbf{1 9 9 0}$ & $\mathbf{2 0 0 0}$ & $\mathbf{2 0 1 0}$ \\
\hline & & & DIS & & & \\
\hline Minimum & 26.27 & 26.80 & 27.46 & 28.88 & 29.68 & 29.97 & 30.69 \\
Maximum & 48.58 & 48.63 & 48.70 & 48.77 & 48.79 & 48.81 & 48.81 \\
Mean & 43.26 & 43.82 & 44.48 & 45.02 & 45.32 & 45.56 & 45.69 \\
Standard dev. & 3.47 & 3.30 & 3.20 & 2.98 & 2.82 & 2.68 & 2.55 \\
\hline & & & & UP & & & \\
\hline Minimum & 0.691 & 0.764 & 0.882 & 1.027 & 1.260 & 1.459 & 1.675 \\
Maximum & 471.236 & 485.941 & 492.475 & 502.658 & 507.823 & 516.026 & 515.605 \\
Mean & 18.797 & 22.611 & 27.955 & 33.895 & 37.597 & 40.826 & 42.442 \\
Standard dev. & 37.806 & 40.739 & 43.724 & 46.599 & 48.033 & 49.414 & 49.913 \\
\hline & & & & LUP & & & \\
\hline Minimum & 0.004 & 0.004 & 0.004 & 0.005 & 0.005 & 0.005 & 0.004 \\
Maximum & 0.107 & 0.126 & 0.149 & 0.176 & 0.194 & 0.217 & 0.235 \\
Mean & 0.043 & 0.049 & 0.059 & 0.070 & 0.076 & 0.080 & 0.080 \\
Standard dev. & 0.018 & 0.020 & 0.023 & 0.026 & 0.028 & 0.030 & 0.031 \\
\hline
\end{tabular}
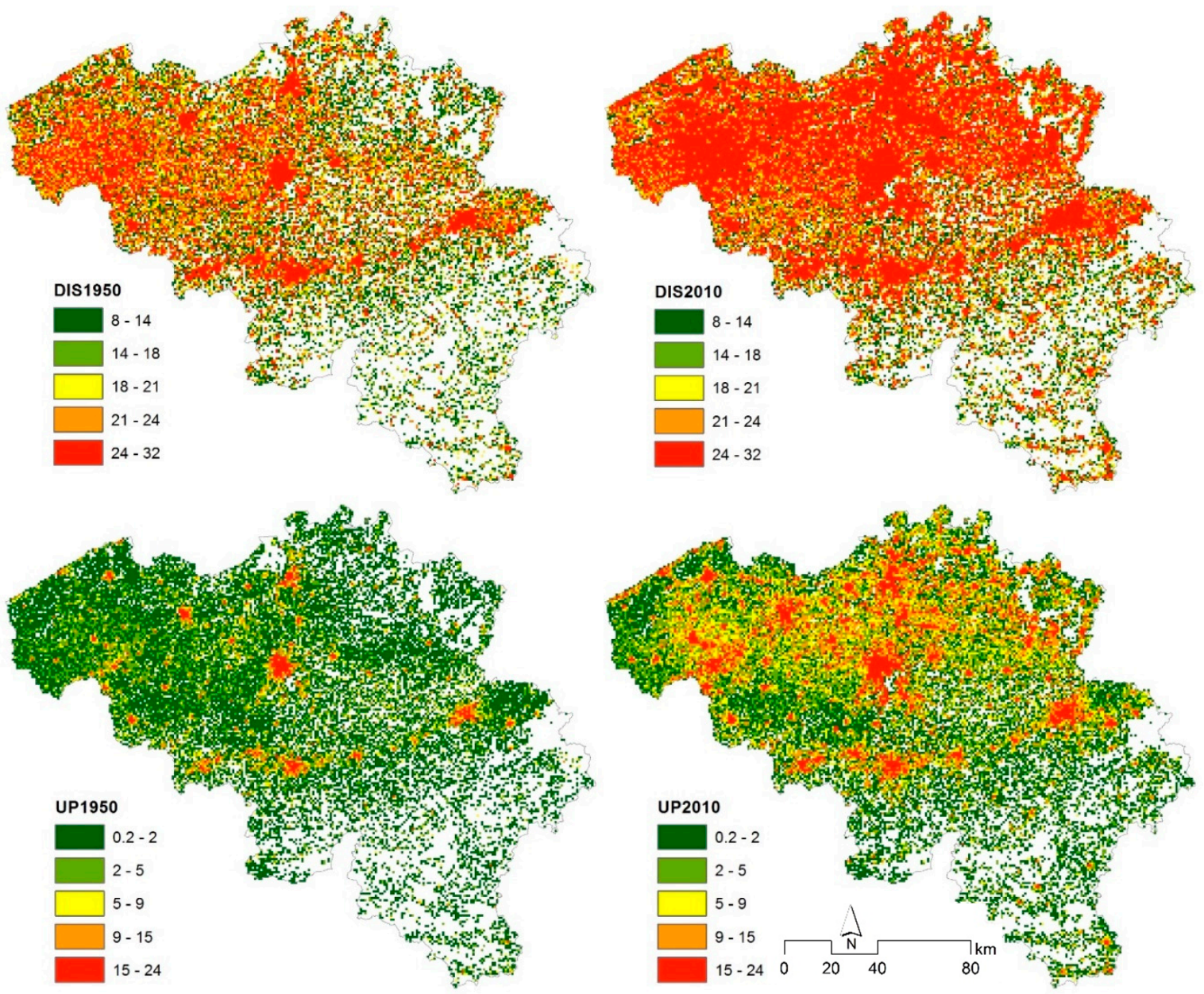

Figure 10. DIS (UPU/m²) and UP (UPU/ $\left./ \mathrm{km}^{2}\right)$ at the $1-\mathrm{km}^{2}$ reporting unit in 1950 and 2010. 
The changes in DIS followed an upward trend until 1980, especially in large parts of northwest Belgium. Since 1980, DIS started declining in most parts of Belgium. UP, on the other hand, continuously affected many locations in Flanders, Brussels, and north Wallonia. Yet a decrease in UP can be found in many locations during the 2000-2010 period.

Table 3 lists the results of linear regression analysis of the relationships between the selected explanatory variables and DIS.

Table 3. Linear regression analysis of the relationship between changes in DIS (delta DIS) in each decade and the selected divers.

\begin{tabular}{lcccccc}
\hline \multicolumn{1}{c}{ Delta DIS } & $\mathbf{1 9 6 0 - 1 9 5 0}$ & $\mathbf{1 9 7 0 - 1 9 6 0}$ & $\mathbf{1 9 8 0 - 1 9 7 0}$ & $\mathbf{1 9 9 0 - 1 9 8 0}$ & $\mathbf{2 0 0 0 - 1 9 9 0}$ & $\mathbf{2 0 1 0 - 2 0 0 0}$ \\
\hline Intercept & 13.501 & 14.717 & 15.841 & 16.502 & 17.038 & 17.346 \\
Previous DIS & $9.251^{*, \ddagger}$ & $9.118^{*, \ddagger}$ & $9.439^{*, \ddagger}$ & $9.781^{*, \ddagger}$ & $9.917^{*, \ddagger}$ & $10.009^{*}$, \\
Dist. To urban cores & $-0.287^{*, \ddagger}$ & $-0.305^{*, \ddagger}$ & $-0.339^{*, \ddagger}$ & $-0.166^{*, \ddagger}$ & $-0.148^{*, \ddagger}$ & $-0.117^{*, \ddagger}$ \\
Elevation & $-0.800^{*, \ddagger}$ & $-1.113^{*, \ddagger}$ & $-0.713^{*, \ddagger}$ & $-0.559^{*, \ddagger}$ & $-0.311^{*, \ddagger}$ & $-0.265^{*, \ddagger}$ \\
Slope & $-0.114^{*, \ddagger}$ & $-0.102^{*, \ddagger}$ & $-0.099^{*, \ddagger}$ & $-0.061^{*}$ & $-0.119^{*, \ddagger}$ & -0.024 \\
$\mathbf{R}^{2}$ & 0.846 & $0.841^{2}$ & 0.861 & 0.894 & 0.901 & 0.911 \\
\hline
\end{tabular}

Significance at: ${ }^{*} p<0.05$ level, ${ }^{\ddagger} p<0.01$ level.

In the 2000-2010 period, the impact of all selected variables on delta DIS, except for slope, is statistically significant. The results reveal that the evolution of DIS can, to a great extent, be predicted by the urban dispersion situation observed in the former decade. DIS shows an extremely strong positive relationship with DIS patterns when compared with other variables. Urban sprawl, hence, appears to be a self-reinforcing process, i.e., the locations that have a high dispersion value will continue to suffer from an increase in dispersion in the future. Even though the rate of change of dispersion progressively slowed down at the national and regional level from the 1980s (Figure 3), it can be seen from Table 2 that the self-reinforcing nature of the process keeps increasing over time. On a local scale, land use plans are not efficient at redirecting urban development to central places, and keep fueling expansion in those places that were already dispersed. In other words, dispersion continued to fuel more dispersion, even after the adoption of land use plans in the 1980s.

The self-reinforcing nature of urban sprawl can be explained by several factors. Obviously, the explanatory variables considered in our model are somehow limited. We did not include accessibility to roads, trains, or jobs in our model. These hidden variables may keep their influence over time and explain why the same trends are observed from one period to another. Still another explanatory factor for this self-reinforcing behavior lies in the very nature of dispersion. Land use policies in Belgium mean that it is usually easier to develop an empty parcel of land when there are already some buildings in its vicinity. Such an empty parcel would often be serviced by roads and basic urban networks (water, electricity, cable). This is usually used as an argument to develop in that area so as to benefit from these services, which obviously fuels more dispersion.

Distance to urban cores has a moderately negative impact on delta DIS patterns. More interestingly, the distance to urban cores took an upward trend between 1950 and 1990, and then this trend decreased. This can be explained, in part, by the increase in car use and the tax regulations in Belgium, which allow car users to deduct their transport costs from their income tax. Together with a dense road network, all cities, villages, and hamlets became efficiently connected over time [30]. The impact of physical variables, elevation, and slope is stronger than the distance to urban cores. The coefficients of both variables signify that the process of increasing urban dispersion tends to occur in lowland and flat locations.

The goodness-of-fit measure for our linear regression analysis, by means of $\mathrm{R}^{2}$, indicates a good fit, with $R^{2}$ values ranging from 0.85 to 0.91 . The $R^{2}$ values in 1960 and 1970, which represent the change in DIS during the periods 1950-1960 and 1960-1970, respectively, are lower than in other time periods, implying that the recent dispersions are more predictable than the former ones. 


\section{Conclusions}

This paper explored the long-term evolution of urban sprawl in Belgium. According to the European Environment Agency report, number 11/2016, entitled "Urban sprawl in Europe", Belgium is the EU country most affected by sprawl. This is the first study that traces sprawl over six decades, beginning in 1950; two decades covering the period before land use plans were introduction in Belgium (1950-1970), two decades during which land use plans were being developed (1970-1990), and two decades after land use plans were adopted (1990-2010). This was done by measuring sprawl evolution and drivers each decade between 1950 and 2010.

We used three urban sprawl indices that measure dispersion (DIS), permeation of a landscape by urban uses (UP), and the area of urban land per inhabitant (LUP). The three indices can be used to compare urban sprawl among regions of different sizes as they use a 'horizon of perception' to unify the scale of analysis. This enabled us to compare the sprawl among the three regions of Belgium (Brussels, Flanders, and Wallonia). The findings of this comparison highlighted the fact that Brussels is the region most affected by DIS and UP. On the other hand, Brussels showed the lowest LUP, which indicates that the utilization of built-up land is much better than in Flanders and Wallonia. These results give an overview of the sprawl evolution in Belgian regions. We therefore performed a further analysis at the municipality and $1-\mathrm{km}^{2}$ levels. Both levels provided more informative analysis and could easily be used by urban planning institutions and municipality and city authorities to identify the variation in sprawl in a given geographical space. The analysis shows that the northwest Belgian and Brussels municipalities are highly affected by sprawl in terms of DIS and UP.

We selected a number of factors and examined the relationship between these factors and DIS as an indicator of sprawl at $1-\mathrm{km}^{2}$. We found that urban sprawl is a self-reinforcing process, i.e., dispersion is fueling further dispersion on a local scale. This may be related to a number of factors, amongst which is the relative lack of efficiency of land use plans. Curbing this phenomenon would require both restrictive land uptake policies at the regional level, as advocated by the European Commission, and much more voluntary policies at the local level so as to direct development in already built areas within municipalities.

Author Contributions: Conceptualization, J.T. and A.M.; methodology, A.M. and J.T.; data processing, A.M.; formal analysis, A.M. and J.T.; writing-original draft preparation, A.M.; writing-review and editing, J.T. and A.M. All authors have read and agreed to the published version of the manuscript.

Funding: This research was funded by the FNRS PDR project SusDens "Sustainable Residential Densification".

Conflicts of Interest: The authors declare no conflict of interest.

\section{References}

1. Ewing, R.; Cervero, R. Travel and the Built Environment. J. Am. Plann. Assoc. 2010, 76, 265-294. [CrossRef]

2. Knaap, G.-J.; Song, Y.; Nedovic-Budic, Z. Measuring Patterns of Urban Development: New Intelligence for the War on Sprawl. Local Environ. 2007, 12, 239-257. [CrossRef]

3. Ewing, R.H.; Pendall, R.; Chen, D.D. Measuring Sprawl and Its Impact; Smart Growth America: Washington, DC, USA, 2002; Volume 1, p. 55.

4. European Environment Agency. FOEN Urban Sprawl in Europe; European Environment Agency: Luxembourg, 2016; pp. 1-140.

5. Ewing, R.H. Characteristics, Causes, and Effects of Sprawl: A Literature Review. In Urban Ecology: An International Perspective on the Interaction between Humans and Nature; Marzluff, J.M., Shulenberger, E., Endlicher, W., Alberti, M., Bradley, G., Ryan, C., Simon, U., ZumBrunnen, C., Eds.; Springer: Boston, MA, USA, 2008; pp. 519-535. ISBN 978-0-387-73412-5.

6. Hennig, E.I.; Schwick, C.; Soukup, T.; Orlitová, E.; Kienast, F.; Jaeger, J.A.G. Multi-scale analysis of urban sprawl in Europe: Towards a European de-sprawling strategy. Land Use Policy 2015, 49, 483-498. [CrossRef] 
7. Halleux, J.-M.; Marcinczak, S.; van der Krabben, E. The adaptive efficiency of land use planning measured by the control of urban sprawl. The cases of the Netherlands, Belgium and Poland. Land Use Policy 2012, 29, 887-898. [CrossRef]

8. Barrington-Leigh, C.; Millard-Ball, A. A century of sprawl in the United States. Proc. Natl. Acad. Sci. USA 2015, 112, 8244-8249. [CrossRef]

9. Terando, A.J.; Costanza, J.; Belyea, C.; Dunn, R.R.; McKerrow, A.; Collazo, J.A. The Southern Megalopolis: Using the Past to Predict the Future of Urban Sprawl in the Southeast U.S. PLoS ONE 2014, 9, e102261. [CrossRef]

10. de Espindola, G.M.; da Carneiro, E.L.N.C.; Façanha, A.C. Four decades of urban sprawl and population growth in Teresina, Brazil. Appl. Geogr. 2017, 79, 73-83. [CrossRef]

11. Fracassi, P.C.; Lollo, J.A. Urban Sprawl in Small Cities, Analysis of the Municipality of São Pedro (Sp): Potentials And Constrains. J. Urban Environ. Eng. (JUEE) 2013, 7, 64-73. [CrossRef]

12. Inostroza, L.; Baur, R.; Csaplovics, E. Urban sprawl and fragmentation in Latin America: A dynamic quantification and characterization of spatial patterns. J. Environ. Manag. 2013, 115, 87-97. [CrossRef]

13. Jiang, F.; Liu, S.; Yuan, H.; Zhang, Q. Measuring urban sprawl in Beijing with geo-spatial indices. J. Geogr. Sci. 2007, 17, 469-478. [CrossRef]

14. Yue, W.; Liu, Y.; Fan, P. Measuring urban sprawl and its drivers in large Chinese cities: The case of Hangzhou. Land Use Policy 2013, 31, 358-370. [CrossRef]

15. Cobbinah, P.B.; Aboagye, H.N. A Ghanaian twist to urban sprawl. Land Use Policy 2017, 61, 231-241. [CrossRef]

16. Musakwa, W.; van Niekerk, A. Monitoring Urban Sprawl and Sustainable Urban Development Using the Moran Index: A Case Study of Stellenbosch, South Africa. Int. J. Appl. Geospat. Res. (IJAGR) 2014, 5, 1-20. [CrossRef]

17. Guastella, G.; Oueslati, W.; Pareglio, S. Patterns of Urban Spatial Expansion in European Cities. Sustainability 2019, 11, 2247. [CrossRef]

18. Albrechts, L. Planners as catalysts and initiators of change. The new structure plan for flanders. Eur. Plann. Stud. 1999, 7, 587-603. [CrossRef]

19. Halleux, J.-M. Outskirts Dynamics and New Residential Developments in Belgium. A Comparative Analysis with the Swiss and Danish Contexts; European Science Foundation: Strasbourg, France, 2004.

20. Lopez, R.; Hynes, H.P. Sprawl in the 1990s: Measurement, Distribution, and Trends. Urban Aff. Rev. 2003, 38, 325-355. [CrossRef]

21. Solon, J. Spatial context of urbanization: Landscape pattern and changes between 1950 and 1990 in the Warsaw metropolitan area, Poland. Landsc. Urban Plan. 2009, 93, 250-261. [CrossRef]

22. Schneider, A.; Woodcock, C.E. Compact, Dispersed, Fragmented, Extensive? A Comparison of Urban Growth in Twenty-five Global Cities using Remotely Sensed Data, Pattern Metrics and Census Information. Urban Stud. 2008, 45, 659-692. [CrossRef]

23. Jaeger, J.A.G.; Bertiller, R.; Schwick, C.; Cavens, D.; Kienast, F. Urban permeation of landscapes and sprawl per capita: New measures of urban sprawl. Ecol. Indic. 2010, 10, 427-441. [CrossRef]

24. Jaeger, J.A.G.; Schwick, C. Improving the measurement of urban sprawl: Weighted Urban Proliferation (WUP) and its application to Switzerland. Ecol. Indic. 2014, 38, 294-308. [CrossRef]

25. Vandenbulcke, G.; Steenberghen, T.; Thomas, I. Mapping accessibility in Belgium: A tool for land-use and transport planning. J. Transp. Geogr. 2009, 17, 39-53. [CrossRef]

26. Mustafa, A.; Saadi, I.; Cools, M.; Teller, J. Understanding urban development types and drivers in Wallonia. A multi-density approach. Int. J. Bus. Intell. Data Min. 2018, 13, 309-330. [CrossRef]

27. Mustafa, A.; Cools, M.; Saadi, I.; Teller, J. Coupling agent-based, cellular automata and logistic regression into a hybrid urban expansion model (HUEM). Land Use Policy 2017, 69, 529-540. [CrossRef]

28. Mustafa, A.; Heppenstall, A.; Omrani, H.; Saadi, I.; Cools, M.; Teller, J. Modelling built-up expansion and densification with multinomial logistic regression, cellular automata and genetic algorithm. Comput. Environ. Urban Syst. 2018, 67, 147-156. [CrossRef]

29. Fulton, W.B.; Pendall, R.; Nguyẽn, M.; Harrison, A. Who Sprawls Most?: How Growth Patterns Differ across the US; Brookings Institution, Center on Urban and Metropolitan Policy: Washington, DC, USA, 2001.

30. De Decker, P. Facets of housing and housing policies in Belgium. J. Hous. Built Environ. 2008, 23, 155-171. [CrossRef]

(C) 2020 by the authors. Licensee MDPI, Basel, Switzerland. This article is an open access article distributed under the terms and conditions of the Creative Commons Attribution (CC BY) license (http://creativecommons.org/licenses/by/4.0/). 